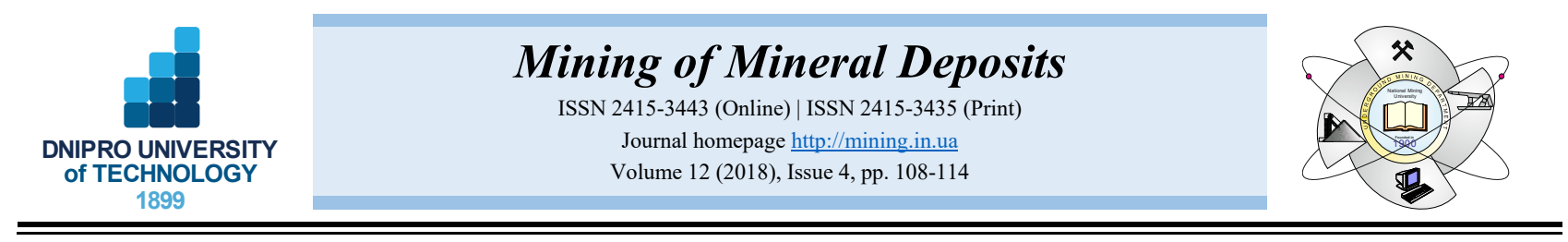

UDC 622.222

https://doi.org/10.15407/mining12.04.108

\title{
SELECTION OF ACCESSING AND DEVELOPMENT SCHEMES FOR EXTRACTING RESERVES OF ORE BODY 2 IN IRTYSH DEPOSIT
}

\author{
L. Krupnik ${ }^{1}$, Yu. Shaposhnik ${ }^{2}$, S. Shaposhnik ${ }^{3}$, A. Konurin ${ }^{2 *}$, D. Shokarev ${ }^{4}$ \\ ${ }^{1}$ Kazakh National Research Technical University named after K.I. Satpayev, Almaty, Kazakhstan \\ ${ }^{2}$ Institute of Mining named after N.A. Chinakal of the Siberian Branch of the Russian Academy of Sciences, Novosibirsk, Russian Federation \\ ${ }^{3}$ D. Serikbaev East-Kazakhstan State Technical University, Ust-Kamenogorsk, Kazakhstan \\ ${ }^{4}$ LLP “Expert PRO”, Ust-Kamenogorsk, Kazakhstan \\ *Corresponding author: e-mail anton.konurin@gmail.com,tel.+73832053030
}

\begin{abstract}
Purpose. Justification and selection of a rational scheme for accessing the second ore body of the Irtysh deposit based on a technical and economic comparison of its adopted competitive options.

Methods. The main mining, geological and engineering requirements for selecting the scheme for accessing the Irtysh field are considered to achieve the goal. Three competitive accessing options are proposed on the basis of project regulatory documents and geotechnological features of the ore body. The optimal scheme of accessing was suggested taking into account the volumes of mining and preparatory works and averaging of the metal content in the ore by the method of technical and economic comparison.

Findings. Analysis of the accessing schemes was performed for deposits similar in the geological conditions and represented by fragmented ore bodies. The advantages and disadvantages of 3 competitive access options are reviewed in detail. The technological and economic feasibility of excavation of ore body 2 reserves has been substantiated, i.e. of accessing them by fringedrifts between the Irtysh and Vspomogatel'naya mines on the upper horizons of the deposit. It is established that the difference in the volume of capital works (CW) and preparatory works (PW) is $45640 \mathrm{~m}^{3}$ in favor of accessing ore body 2 by fringedrifts between the Irtysh and Vspomogatel'naya mines. At the same time, the volumes of CW and PW at the initial and final stages of development are much lower than in the case of accessing by a transport ramp from the surface. The change in the average content of copper, lead and zinc with the simultaneous development of the Osnovnaya Deposit and the South-Eastern Deposit in the lower horizons of the field has been calculated.
\end{abstract}

Originality. For the conditions of ore body 2 of the Irtysh deposit, planned for development in accordance with the proposed access, it was found that despite the decrease in the copper content in the saleable ore, the lead content in the saleable ore will increase to $0.49 \%$ and zinc content, respectively, to $3.83 \%$.

Practical implications. Mining of ore body 2 according to the recommended accessing scheme with a minimum amount of mining will allow to raise the productivity of the Irtysh mine to 600 thousand tons per year during the period 2018 - 2026, as well as to increase the extraction of lead and zinc.

Keywords: deposit, ore body, accessing scheme, mining volume, mineral content

\section{INTRODUCTION}

High efficiency of developing mineral deposits, represented by fragmented ore bodies, under the condition of their partial operation, should be achieved due to small capital investments, short payback period, as well as the use of simple accessing schemes and refining technology. The main deterrent to the intensive development of deposits from fragmented ore bodies is the weak methodological support for the selection of rational accessing schemes that take into account mining and geological features of these deposits and the improvement of the extracted mineral quality.

The main ore bodies of the Irtysh polymetallic deposit are the Osnovnaya and South-Eastern deposits, which successively replace one another along strike. Reserves of the Osnovnaya deposit are primarily developed, with ore remaining in inter-chamber and safety pillars and in small quantities in the edge reservoir area. Ore reserves in the upper part of South-Eastern deposit are mainly

(C) 2018. L. Krupnik, Yu. Shaposhnik, S. Shaposhnik, A. Konurin, D. Shokarev. Published by the Dnipro University of Technology on behalf of Mining of Mineral Deposits. This is an Open Access article distributed under the terms of the Creative Commons Attribution License (http://creativecommons.org/licenses/by/4.0/),

which permits unrestricted reuse, distribution, and reproduction in any medium, provided the original work is properly cited. 
developed. Currently, there is a need to access and mine dispersed ore bodies in the upper horizons of the deposit to maintain the mine's production capacity of 600 thousand tons of ore per year.

The ore reserves are exhausted, and the level of mining operations in the Osnovnaya and South-Eastern deposits of the Irtysh deposit is reduced. It is necessary to put into operation ore bodies 2,3 and 4 that have not been processed yet at the upper horizons of the deposit in order to maintain the production capacity of the Irtysh mine at 600 thousand tons of ore per year.

Accessing of this site is scheduled in the development program of the Irtysh mine, which will increase the production capacity of the mining enterprise. Studies aimed at scientific and methodological substantiation of technological solutions for accessing and further development of fragmented ore bodies are considered relevant because ore bodies 2, 3 and 4 and Novaya deposit are not yet accessed.

\section{ANALYSIS OF ACCESSING PATTERNS APPLIED TO THE DEVELOPMENT OF CONTIGUOUS ORE BODIES}

There is a history of experience in accessing similar deposits represented by contiguous ore deposits in eastern Kazakhstan. Thus, at the Sekisovskoe gold deposit, accessing of fragmented ore bodies No. 2, 5-8, 10 and 11 is carried out by a transport ramp, going from the bottom ( $+310 \mathrm{~m}$ elevation) of the Main pit to the level $-25 \mathrm{~m}$ developed by air-feeding, air-exhausting and lift raises. A distinctive feature of the deposit is contiguous ore bodies $1.5-2.5 \mathrm{~m}$ thick with areas of enclosing rocks $3-8 \mathrm{~m}$ and more (Nurseitova, Ilyasov, \& Shaposhnik, 2014). The share of low-grade ore bodies on horizons ranges from 30 to $50 \%$ of ore reserves. The dip of ore bodies is $70-90^{\circ}$. Often most the host rocks have medium rather than strong resistance. Ore strength by Protod'yakonov scale is $f=8-10$. The ores are valuable, because they contain $5.23 \mathrm{~g} / \mathrm{t}$ of gold and $6.90 \mathrm{~g} / \mathrm{t}$ of silver. The rated annual output of the underground mine is 500 thousand tons of ore (Krupnik, Bitimbaev, Shaposhni, Shaposhnik, \& Demin, 2015).

Mining and geological conditions of the Sekisovskoe deposit allowed laying a transport ramp in the center of the field. This made it possible to significantly reduce the volume of mining works for accessing and preparation of isolated ore bodies located on the flanks of the deposit, to simplify the scheme for transporting ore by selfpropelled equipment to the surface ore stockpile, and to reduce the cost of mine ventilation.

However, mining of the Sekisovskoe deposit by development systems with caving of enclosing rocks from the horizon $+320 \mathrm{~m}$ to the horizon $-20 \mathrm{~m}$ is constantly accompanied by a decrease in the metal content of the saleable ore (by $7.72 \%$ of gold and $27.9 \%$ of silver during the period of 2013 - 2019). In addition, according to this scheme of accessing, it is planned to stope all the reserves of fragmented ore bodies No. 2, 5-8, 10 and 11 within the level, after which it will be possible to stope these ore bodies on the underlying level. This sequence is explained by the rigid connection between mining of ore bodies, their ventilation and schemes of miners' evacuation in emergency situations. The above considerations explain why it is impossible to consistently maintain the quality indicators of ore in the process of the field mining.

Another example of accessing contiguous ore deposits is the Suzdal gold ore deposit. It is represented by ore zones $1-3,2$ and 4. Ore zone 4 is separated from ore zones $1-3$ and 2 by the distance of $900 \mathrm{~m}$, which necessitated their separate accessing (Petrov, Zhumadilov, \& Shaposhnik, 2014).

Accessing of the Suzdal field is determined by taking into account the geological and engineering conditions (Krupnik, Shaposhnik, \& Shaposhnik, 2011):

- relatively shallow depth of ore bodies (ore zones $1-3,2$ at the depth of $550-600 \mathrm{~m}$, ore zone $4-$ at $350 \mathrm{~m}$ );

- spatial location of the ore bodies constituting the ore zones dispersed along the strike and dip;

- short deadlines for commissioning the lower horizons of ore zones $1-3,4$ and construction of facilities and structures for commissioning of the ore zone 4;

- terrain and the presence of the waste pits;

- application of self-propelled loading and transport equipment in the preparation, excavation and transportation of the rock mass in blocks and horizons;

- existing capital openings.

Thus, accessing of the separated ore bodies of the ore zones $1-3$ and 2 was carried out by two road ramps, two elevator and ventilation raises.

Primary ores in the ore zone $1-3$, represented by five ore bodies, and in the ore zone 2 , represented by five ore bodies, are accessed together, which also allows to significantly reduce capital investments and operational costs for the extraction of ore reserves.

With mine design capacity at 550 thousand tons of ore per year and the average metal content in the saleable ore from the ore zone $1-3-9.94 \mathrm{~g} / \mathrm{t}$, ore zone $2-$ $7.14 \mathrm{~g} / \mathrm{t}$, the deterioration of the mined ore quality is predictable: by the end of the ore zone $1-3$ mining (2019) - at $3.4 \%$; by the end of the ore zone 2 mining (2021) - at $25.7 \%$.

While accessing ore deposits at greater depths, it is advisable to study and assess changes in the stress-strain state of the rock massif, depending on the variation of ore deposits excavation sequence. So, the geomechanical substantiation of the parameters characterizing excavation of Oktyabr'skiy northern deposits of the Glubokaya mine was carried out on the basis of 3-D parametric model developed in accordance with the geological surveying documentation presented in the form of vertical sections and plans (Neverov, Neverov, Shaposhnik, \& Konurin, 2018). The developed forecast maps of stress distribution in the rock massif depending on the order of excavation development allowed to establish the practically absent (at the scale level) or minimal influence of mined deposits on each other, which, in general, makes it possible to implement different variants of the development sequence. A geomechanical assessment of mining situation was also conducted at the Irtysh field (Zhirnov, Shaposhnik, Nikolsky, \& Neverov, 2018).

The analysis of foreign and domestic experience has shown significant technological and organizational advantages and high efficiency of the improved field accessing schemes by road ramps compared to the use of vertical elevator shafts. An essential role is played by the 
method of accessing by motor transport ramps when stoping thin ore bodies separated along strike and dip in difficult mining and geological conditions with low confidence of ore deposits' preliminary exploration. (Sadvakasov, Zhunusov, Egorochkin, Akashev, 2007).

Auto-transport ramps, like ventilation workings and emergency mechanized exits with transportation of rock mass and people by road, are provided at the Suzdal mine of Alel JSC, Sekisovskoe mine, Maleevskiy mine of Kazzinc, Obruchevskiy and Dolin mines of Kazzinc, Talap and Vesennee-Aralchinskoe deposits (Erofeev, Nikiforov, Cherkasov, \& Fabrichnov, 1989; Beisebayev, Bitimbaev, \& Daukeev, 1997; Barilyuk, Ananin, \& Ort, 2003; Kaplunov, Kalmykov, \& Rylnikova, 2003; Ryabov et al., 2005) and others. Thus, at the moment, the issues of accessing ore body 2 of the Irtysh deposit or fields with similar geotechnological conditions are insufficiently covered in literature, which is of scholarly interest for the mining science (design) of this region.

\section{GEOTECHNOLOGICAL CONDITIONS FOR THE DEVELOPMENT OF THE IRTYSH FIELD}

The Irtysh deposit is located in the foothill part of the Rudnyy Altai within the smoothed bald mountain passing into the plain. Absolute elevations are from 360 to $490 \mathrm{~m}$. The main ore-bearing structure is the zone of increased shale of effusive-sedimentary rocks converted during the hydrothermal alteration into microquartzites sericite-quartz, chlorite-sericite-quartz formations. Microquartzites are developed mainly in the hanging side of the deposit, which has a shale texture. Sericite-quartz schists are most common in the lying side of the deposit in the immediate vicinity of ore bodies. The rocks of the hanging side are represented by chlorite-sericite-quartz schists, whose strength is $f=15$ on Protod'yakonov scale. Stability is average, sustainability category is III. The rocks are split and fractured in different degrees. The maximum schistosity of rocks is noted near ore bodies (Zhaksylykov, Frolov, \& Kozlov, 1981; Feasibility study of industrial..., 2013).

The deposit was accessed by the shafts of mines Vspomogatel'naya, Skipovaya and Irtysh up to horizon 15, mine RESH - up to horizon 14 (Industrial development project..., 2010). The distance between the Skipovaya and Vspomogatel'naya shafts on the one side and the Irtysh mine, located on the southeastern flank, on the other side, is $3.2-3.3 \mathrm{~km}$. Further access- ing and preparation is carried out by stoping the field haulage drifts to the entire length of the Osnovnaya and South-Eastern deposits (up to $4.5 \mathrm{~km}$ ) with crossovers (transport races), accessing the ore bodies at full power in $100 \mathrm{~m}$ along the strike, at each of the operational horizons located each 50 meters vertically. Transportation of the mined ore from the horizons is carried out by rail transport, i.e. mine overhead wire locomotives KR 10 carrying VG 2.2 trolleys to the central ore disposal at the Skipovaya shaft. All extracted ore goes along the concentration horizon 13 to the crushing and dosing complex of the Skipovaya shaft and then - to the receiving hopper on the surface by skips. The rock is transported in trolleys UVB 1.6 (with lateral unloading) to the central rock formation, along horizon 13 to the Skipovaya shaft and is further delivered to the rock dump on the surface.

The deposit is completely covered by a layer of $\mathrm{Ce}$ nozoic clays and loams from the surface. In addition to the Osnovnaya deposit, ore bodies 2 and 3 have a partial outlet to the erosion section (under the sediment). Thickness of the Cenozoic deposits over ore body 2 is from 10 to $40 \mathrm{~m}$, and over body 3 - from 3 to $10 \mathrm{~m}$. The ore is partially oxidized in the near-surface part, while there are no actually oxidized ores, there is a mixed type of ores. The boundary between mixed and sulphide ores for ore body 2 goes at a depth of $70-120 \mathrm{~m}$ in the southeastern and central parts, gradually sinking in the northwest direction to depths of $160-220 \mathrm{~m}$. As a result, nearsurface ores of the central part, as well as the entire northwestern part of the belt of ore body 2, (700 $\mathrm{m}$ along the strike), are represented by a mixed type of ore. Single non-productive intersections (mineralization zone) that have no practical interest in terms of estimating mixed ore reserves are available only for the near-surface zone of ore body 3 partial oxidation.

The ore body 2 is represented by three imbricate lenses of sulphide ores. The length of ore bodies is: along the strike $-2300 \mathrm{~m}$, along the dip - from 30 to $200 \mathrm{~m}$ (average $120 \mathrm{~m}$ ); the maximum thickness of ore bodies is $5.3 \mathrm{~m}$ (average $1.3 \mathrm{~m}$ ), the depth - from 70 to $300 \mathrm{~m}$. Ore bodies are steeply dipping $\left(80-90^{\circ}\right)$. Ores and enclosing rocks are of medium resistance to the unstable ones, ores are of medium-strength $(f=12)$, enclosing rocks are of medium $(f=7-9)$ and below medium strength $(f=4-6)$, straddled and jointed. Information on the parameters of ore deposits and bodies is presented in Table 1.

Table 1. Linear parameters of the main ore bodies of the Irtysh deposit

\begin{tabular}{|c|c|c|c|c|c|c|c|c|c|}
\hline \multirow{3}{*}{ Ore bodies } & \multicolumn{4}{|c|}{ Length of ore bodies, $\mathrm{m}$} & \multicolumn{2}{|c|}{ Thickness, $\mathrm{m}$} & \multicolumn{2}{|c|}{ Depth, m } & \multirow{3}{*}{$\begin{array}{l}\text { Angles of } \\
\text { fall, deg. }\end{array}$} \\
\hline & \multirow{2}{*}{$\begin{array}{l}\text { Along } \\
\text { the } \\
\text { strike }\end{array}$} & \multicolumn{3}{|c|}{ Along the fall } & \multirow{2}{*}{ maximum } & \multirow{2}{*}{ average } & \multirow{2}{*}{ from } & \multirow{2}{*}{ to } & \\
\hline & & from & to & average & & & & & \\
\hline Main deposit & 2700 & $70-100$ & 600 & 390 & 19.3 & 3.8 & $0^{*}$ & 740 & $50-90$ \\
\hline Ore body 1 & 780 & 40 & 60 & 50 & 13.2 & 3.1 & 330 & 480 & $85-90$ \\
\hline Parallel deposit & 750 & 50 & 80 & 70 & 4.9 & 1.6 & 250 & 330 & $60-70$ \\
\hline South-East deposit & 3300 & $60-100$ & 500 & 310 & 22.4 & 3.0 & 400 & 900 & $80-90$ \\
\hline Ore body 2 & 2300 & 30 & 200 & 120 & 5.3 & 1.3 & $70^{* *}$ & 300 & $80-90$ \\
\hline Ore body 3 & 700 & 40 & 80 & 70 & 3.9 & 2.5 & $80^{* *}$ & 190 & $80-90$ \\
\hline Ore body 4 & 440 & - & - & 110 & 2.2 & 0.8 & 100 & 300 & $80-90$ \\
\hline New deposit & 1500 & 80 & 170 & 140 & 6.5 & 3.0 & 630 & 870 & $60-90$ \\
\hline Ore lens 202 & 580 & 40 & 80 & 70 & 6.4 & 2.1 & 680 & 830 & $60-90$ \\
\hline
\end{tabular}

${ }^{*}$ - without Cenozoic deposits; ${ }^{* *}$ - without oxidized and mixed ores 


\section{METHODOLOGICAL ASPECTS OF CHOOSING COMPETITIVE ACCESSING SCHEMES}

Option for accessing ore body 2 should be selected taking into account the following geological and engineering conditions:

- relatively small depth of ore bodies' occurrence (300 $\mathrm{m}$ under the surface);

- spatial arrangement along the strike and dip of ore body 2 ;

- short deadlines for commissioning of working horizons and construction of the facilities for starting development of the ore zone;

- topography;

- application of self-propelled drilling, handling and transport equipment in the preparation, cleaning and transportation of rock in blocks and horizons;
- actual location of the existing surface facilities of the enterprise.

In accordance with the current rules (Norms of technological design..., 1986; Rules for ensuring industrial.., 2014), scheme No. 1 (Fig. 1) is proposed for accessing ore body 2 with an inclined transport ramp from the surface, which includes drilling of the following excavations:

- main opening - transport ramp from the surface (mark $+489.17 \mathrm{~m}$ ) to the mark of $+171 \mathrm{~m}$ on the southeast flank of the field in the Irtysh mine shaft area;

- ramps from the transport gradient at elevations of $+321,+271,+221,+171 \mathrm{~m}$;

- fringedrifts every $50 \mathrm{~m}$ vertically at elevations of $+321,+271,+221,+171 \mathrm{~m}$.

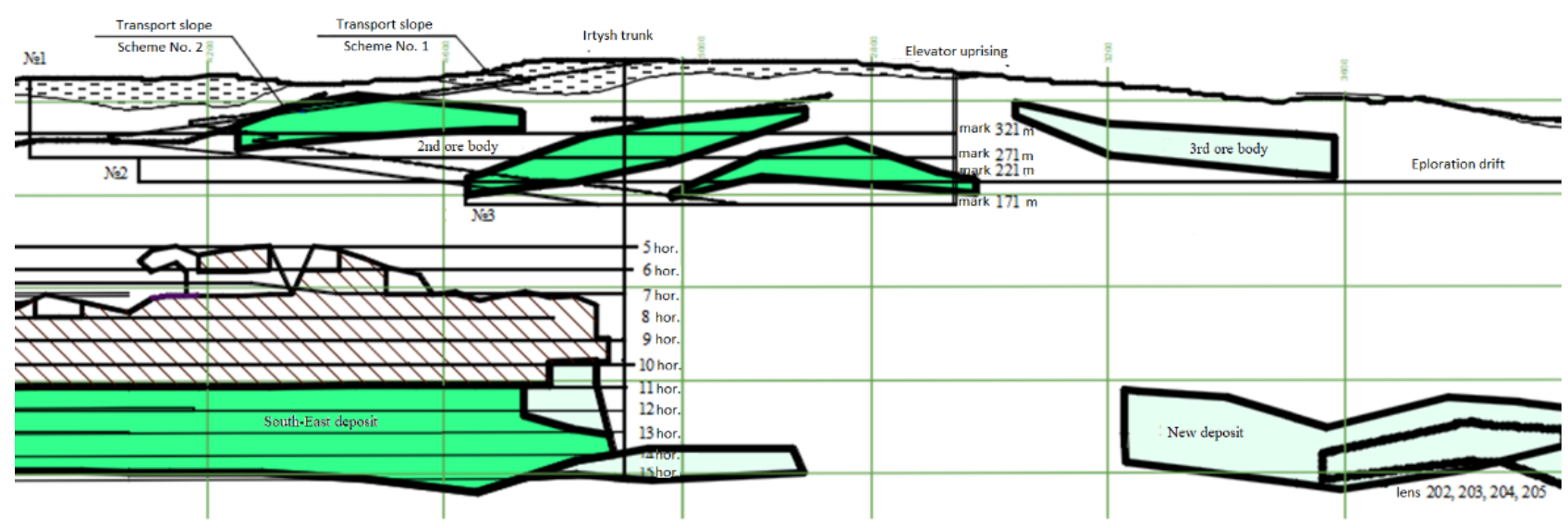

Figure 1. Schemes No. 1 and 2 of ore body 2 accessing in the Irtysh deposit

Two separate exits for people from each horizon directly from the mark of $+171 \mathrm{~m}$ to the surface are provided by stoping the elevator raise with the section of $10.0 \mathrm{~m}^{2}$ $(2.8 \times 3.57 \mathrm{~m})$ and the length of $320 \mathrm{~m}$. Ventilation raise, having access to the day surface, is developed for ventilation of mining operations horizons. The use of the lift ALIMAK SE 700 FC or PSL-1000 is possible for evacuation of people in emergency situations taking into account section of the raise and the performed calculations.

Elevator raise can be developed by drilling (by a drilling machine Rhino- $2000 \mathrm{C}$, diameter of the raise $D=3687 \mathrm{~mm}$, pilot well with a diameter $349 \mathrm{~mm}$, drill bit - Pilot Bits - 349 SCMH), sweep head $3687 \mathrm{~mm}$ (expander CRH 10 E). Eastern Kazakhstan companies have already accumulated certain experience in drilling ventilation shafts $250 \mathrm{~m}$ deep of $3.13 \mathrm{~m}$ dia by the tool Rhino 1298 DC (Sandvik) at Maleevskiy mine of Zyryanovskiy ore-dressing and processing enterprise (ODaPE) and by Rhino 1200 and 400 at Tishinskiy mine of Ridder ODaPE, JSC Kazzinc. Drilling of three shafts $3.1 \mathrm{~m}$ dia by the Rhino tool is planned for accessing the Dolinnoe and Obruchevskoe deposits of Ridder ODaPE (the speed of stoping a pilot well is $300 \mathrm{~m}$ per month, for the extension - $160 \mathrm{~m}$ per month).

Scheme No. 1 allows to solve problems of accessing and preparation of the upper horizons reserves in the deposit (ore body 2) and further ore body 3 . The projected main openings are located beyond the boundaries of the possible zone of rock mass displacement.
Scheme No. 2 of accessing ore body 2 by an inclined transport ramp from the surface of the mark $+454.16 \mathrm{~m}$ to the northwest of the Irtysh mine (Fig. 1) allows to reduce the volume of mining and $\mathrm{CW}$. However, in this case, the volumes of stoping the transport ramp along sediments increase. The ventilation scheme is assumed to be forced. Fresh air is supplied by ventilation and elevator raises. The exhaust air is delivered to the surface along the transport ramp.

Scheme No. 3 presupposes stoping by fringedrifts between the Irtysh and Vspomogatel'naya mines on the upper horizons:

- designing pit-bottom of the Irtysh mine shaft at levels $+321,+271,+221,+171 \mathrm{~m}$;

- stoping crosscuts of the Irtysh mine shaft at levels of $+321,+271,+221,+171 \mathrm{~m}$;

- stoping fringedrifts at $50-\mathrm{m}$ interval vertically at $+321,+271,+221,+171 \mathrm{~m}$.

\section{TECHNICAL AND ECONOMIC COMPARISON OF THE ACCESS OPTIONS}

Scheme No. 3 allows to solve questions of accessing and preparation of the deposit upper horizons reserves (ore body 2) and further - ore bodies 3 and 4 . The projected main openings are located beyond the boundaries of the possible zone of rock mass displacement. The difference in the volume of $\mathrm{CW}$ and $\mathrm{PW}$ is $45640 \mathrm{~m}^{3}$ in favor of the option of accessing ore body 2 by fringedrifts between the Irtysh and Vspomogatel'naya mines (Fig. 2). 


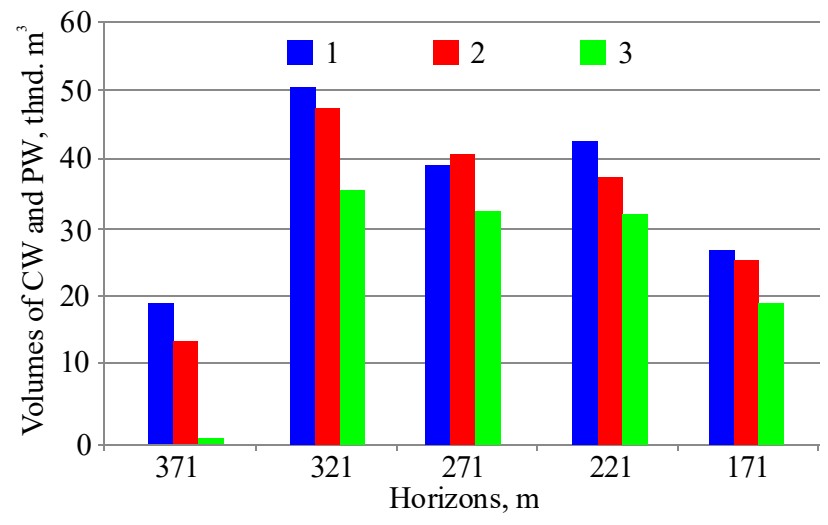

Figure 2. The diagram of capital works and preparatory works in the horizons at different variants of ore body 2 accessing: 1-scheme No. 1; 2-scheme No. 2; 3 - scheme No. 3

The volumes of CW and PW at the initial and final stages of development are much lower than in the case of accessing the ore by a transport ramp from the surface.

Ore body 2 is supposed to be developed by systems with natural or induced caving of overlapping rocks using portable equipment. Taking into account the simultaneous mining of ore body 2 and ore reserves of the lower horizons of the Irtysh deposit with the aim of averaging the metal content in the ore and maintaining the production capacity of the Irtysh mine, we finally take the annual production capacity for the extraction of the ore body reserves to be 200 thousand tons of ore per year (Norms of technological design..., 1986). Joint mining of ore veins with the formation of a single scheme for transportation of rock mass, ventilation and arrangement of emergence mechanized exits to the surface, considering existing openings, is envisaged to maintain annual ore production capacity.

The main advantages of the scheme of accessing ore body 2 reserves by fringedrifts are:

- reduction of capital and preparatory works volumes by $45640 \mathrm{~m}^{3}$;

- absence of necessity to purchase and install the main air handling unit on the surface (use of fresh air coming along the trunk of the Irtysh trunk);

- absence of necessity to carrying out and reinforce the main opening from the surface by sediment;

- reduction of capital and preparatory workings section, which will positively influence the stability of the workings and reduce the costs of their fastening and maintenance;

- earlier dates for the first start-up stage, which will allow faster recoupment of initial capital costs;

- absence of necessity to purchase expensive selfpropelled equipment, using the portable equipment already mastered in the mine.

The main drawbacks of accessing ore body reserves 2 by fringedrifts:

- the need to work on the technological withdrawal of cross-cuts on intermediate horizons when feeding $103 \mathrm{~m}^{3} / \mathrm{s}$ of fresh air along the Irtysh mine shaft to the lower horizons and maintaining the shaft as an emergence exit to the surface;
- the need to form pit-bottoms in the Irtysh mine shaft on intermediate horizons, including the need for additional costs for laying the railway, setting the contact system, purchasing overhead wire locomotives and trolleys, loading machines, etc.;

- reduction in the amount of fresh air supplied to the lower horizons along the Irtysh mine shaft, since part of it will be taken up for ventilation of tunneling and cleaning works during mining of ore body 2 . Ventilation of mine workings of the Irtysh mine is carried out according to the central scheme by the suction method due to the depression created by the fan of the main ventilation VTSD-31.5.

However, the advantages of the proposed scheme for accessing ore body 2 by fringedrifts still exceed its disadvantages, and this scheme of accessing is more rational.

Mining reserves of ore body 2 with an average copper content of $0.84 \%$ with simultaneous development of the Main Deposit and the South-Eastern Deposit on the lower horizons will reduce the copper content in commercial grade ore in the mine as a whole (Fig. 3).

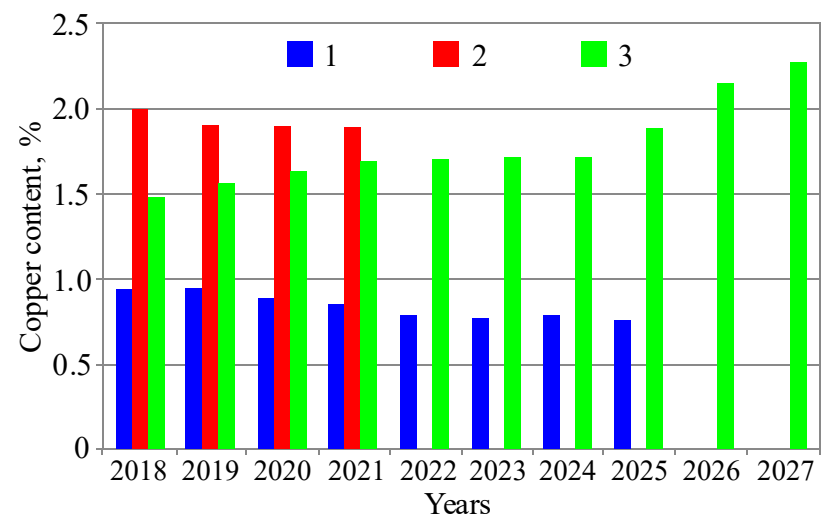

Figure 3. Dynamics of copper content in commercial grade ore in the Irtysh mine during ore body 2 mining: 1 -ore body 2; 2 -main deposit; 3 -South-Eastern deposit

Thus, the content of copper in saleable ore will decrease from 1.95\% (Osnovnaya deposit) and 1.79\% (Southeast deposit) to $1.68 \%$ (in the whole mine) (Fig. 3). However, the lead content in saleable ore will increase from $0.42 \%$ (Osnovnaya deposit) and $0.46 \%$ (Southeast deposit) to $0.49 \%$ (in the whole mine), zinc from 3.12\% (Osnovnaya deposit) and 3.63\% (Southeast deposit) to $3.83 \%$ (in the whole mine). This will allow to efficiently mine the available reserves.

\section{CONCLUSIONS}

Analysis of merits and demerits of the considered ore body 2 access schemes, taking into account the possible risks associated with carrying out and strengthening the transport ramp from the surface along the sediments, has shown that a more attractive and economically expedient option is accessing by fringedrifts between the Irtysh and Vspomogatel'naya mines.

In developing the design documentation for mining ore body 2 , it is advisable to consider the issue of additional exploration of reserves from ore bodies 3 and 4 and, on its basis, to carry out the necessary geological 
survey. It is also possible to consider the expediency of using the existing horizon 6 as a concentration horizon for the passage of ore and rock from marks 321, 271, $221,171 \mathrm{~m}$, followed by the issuance of ore and rock along the Irtysh mine shaft, which eventually will allow to average ores of lower horizons and ore body 2 in terms of their quality.

The extraction of ore along ore body 2 is planned to begin in 2018 with a volume of 9180 tons. In $2019-$ 2021, the ore body 2 will achieve maximum ore output of 200 thousand tons. Mining of ore body 2 will end in 2022 at 58419 tons per year.

Mining of ore body 2 will allow to reach the productivity of the Irtysh mine at 600 thousand tons per year in the period $2018-2026$. The main development system in the relevant mining and geological conditions for the Irtysh deposit (with medium stability of ore and enclosing rocks) is a system with ore storage with the following indicators: specific volume of preparatory works $70.3 \mathrm{~m}^{3} / 1000 \mathrm{t}$; specific volume of first workings $14.4 \mathrm{~m}^{3} / 1000 \mathrm{t}$; losses $-8.9 \%$.

\section{ACKNOWLEDGEMENTS}

The paper did not originate under any project and no funding was raised.

\section{REFERENCES}

Barilyuk, A.I., Ananin, A.I., \& Ort, V.G. (2003). Experience in the use of self-propelled loading and unloading machines at the Orel mine. Gornyi Zhurnal, (1), 56-58.

Beisebayev, A.M., Bitimbaev, M.Zh., \& Daukeev, S.Zh. (1997). Mining-geological reference book on the development of ore deposits. Almaty: Information and presentation center of MSC RK.

Erofeev, I.E., Nikiforov, I.M., Cherkasov, I.P., \& Fabrichnov, S.M. (1989). Underground mining of polymetallic ore deposits. Moscow: Nedra.

Feasibility study of industrial conditions for pyrite-polymetallic ores of the Irtysh deposit. (2013). Almaty: LLP "Geolservis".

Industrial development project of $14^{\text {th }}$ horizon of the Irtysh deposit of polymetallic ores (accessing and working of $14^{\text {th }}$ horizon of the Irtysh deposit). (2010). Belousovka: Production Association Vostoktsvetmet.

Kaplunov, D.R., Kalmykov, V.N., \& Rylnikova, M.V. (2003). Combined geotechnology. Moscow: Publishing House "Ore and Metals".

\section{ОБГРУНТУВАННЯ І ВИБІР СХЕМИ РОЗКРИТТЯ ДЛЯ ВИЇМКИ ЗАПАСІВ ДРУГОГО РУДНОГО ТІЛА ІРТИШСБКОГО РОДОВИЩА}

\section{Л. Крупник, Ю. Шапошник, С. Шапошник, А. Конурін, Д. Шокарєв}

Мета. Обгрунтування та вибір раціональної схеми розкриття другого рудного тіла Іртишського родовища на підставі техніко-економічного порівняння іiї прийнятих конкурентних варіантів.

Методика. Для досягнення поставленої мети виділено основні гірничо-геологічні та інженерно-технічні вимоги для вибору схеми розкриття Іртишського родовища. На підставі положень проектних нормативних документів і геотехнологічних особливостей рудного тіла запропоновані 3 конкурентних варіанти розкриття. Методом техніко-економічного порівняння приймалася оптимальна схема розкриття з урахуванням об'ємів гірничокапітальних і підготовчих робіт та усереднення вмісту металу в руді.

Результати. Виконано аналіз схем розкриття, аналогічних за гірничо-геологічними умовами родовищ, представлених зближеними рудними покладами. Детально розглянуті переваги й недоліки 3 конкурентних варіантів розкриття. Обгрунтована технологічна та економічна доцільність виїмки запасів рудного тіла 2, а саме розкриття польовими штреками між шахтами “Іртишська” і “Допоміжна” на верхніх горизонтах родовища. Встановлено, що різниця в об’ємах гірничо-капітальних (ГКР) і підготовчих робіт (ГПР) становить 45640 м на користь 
варіанту розкриття рудного тіла 2 польовими штреками між шахтами “Іртишська” і “Допоміжна”, при цьому об’єми ГКР і ГПР на початковій і кінцевій стадіях відпрацювання значно нижче, ніж при варіанті розкриття транспортним ухилом з поверхні. Підрахована зміна середнього вмісту міді, свинцю і цинку з одночасним відпрацюванням Основного та Південно-Східного покладів на нижніх горизонтах родовища.

Наукова новизна. Для умов рудного тіла 2 Іртишського родовища, яке планується розробляти, відповідно до запропонованого варіанту розкриття, встановлено, що, незважаючи на зниження вмісту міді у товарній руді, в цілому по руднику підвищиться вміст свинцю в товарній руді до 0.49\%, а цинку - до 3.83\% відповідно.

Практична значимість. Введення у відпрацювання рудного тіла 2, відповідно до рекомендованої схеми розкриття з мінімальним об'ємом гірничих робіт, дозволить досягти продуктивності Іртишського рудника до 600 тис. т на рік у період 2018 - 2026 pр., а також додатково підвищити витяг свинцю і цинку.

Ключові слова: родовище, рудне тіло, схема розкриття, об'єм гірничих робіт, вміст корисного компонента

\section{ОБОСНОВАНИЕ И ВЫБОР СХЕМЫ ВСКРЫТИЯ ДЛЯ ВЫЕМКИ ЗАПАСОВ ВТОРОГО РУДНОГО ТЕЛА ИРТЫШСКОГО МЕСТОРОЖДЕНИЯ}

\section{Л. Крупник, Ю. Шапошник, С. Шапошник, А. Конурин, Д. Шокарев}

Цель. Обоснование и выбор рациональной схемы вскрытия второго рудного тела Иртышского месторождения на основании технико-экономического сравнения ее принятых конкурентных вариантов.

Методика. Для достижения поставленной цели выделены основные горно-геологические и инженернотехнические требования для выбора схемы вскрытия Иртышского месторождения. На основании положений проектных нормативных документов и геотехнологических особенностей рудного тела предложены 3 конкурентных варианта вскрытия. Методом технико-экономического сравнения принималась оптимальная схема вскрытия с учетом объемов горно-капитальных и подготовительных работ и усреднения содержания металла в руде.

Результаты. Выполнен анализ схем вскрытия, аналогичных по горно-геологическим условиям месторождений, представленных сближенными рудными залежами. Детально рассмотрены достоинства и недостатки 3 конкурентных вариантов вскрытия. Обоснована технологическая и экономическая целесообразность выемки запасов рудного тела 2, а именно вскрытие полевыми штреками между шахтами “Иртышская" и “Вспомогательная” на верхних горизонтах месторождения. Установлено, что разница в объемах горно-капитальных (ГКР) и подготовительных работ (ГПР) составляет $45640 \mathrm{~m}^{3}$ в пользу варианта вскрытия рудного тела 2 полевыми штреками между шахтами “Иртышская" и “Вспомогательная”, при этом объемы ГКР и ГПР на начальной и конечной стадиях отработки значительно ниже, чем при варианте вскрытия транспортным уклоном с поверхности. Подсчитано изменение среднего содержания меди, свинца и цинка с одновременной отработкой Основной и Юго-Восточной залежей на нижних горизонтах месторождения.

Научная новизна. Для условий рудного тела 2 Иртышского месторождения, планируемого к разработке, согласно предложенному варианту вскрытия, установлено, что, несмотря на снижение содержание меди в товарной руде, в целом по руднику повысится содержание свинца в товарной руде до $0.49 \%$, а цинка - до $3.83 \%$ соответственно.

Практическая значимость. Ввод в отработку рудного тела 2 , согласно рекомендованной схеме вскрытия с минимальным объемом горных работ, позволит достичь производительности Иртышского рудника до 600 тыс. т в год в период 2018 - 2026 гг., а также дополнительно повысить извлечение свинца и цинка.

Ключевые слова: месторождение, рудное тело, схема вскрытия, объем горных работ, содержание полезного компонента

\section{ARTICLE INFO}

Received: 2 June 2018

Accepted: 3 December 2018

Available online: 19 December 2018

\section{ABOUT AUTHORS}

Leonid Krupnik, Doctor of Technical Sciences, Professor of the Department of Mining and Metallurgical Machinery and Equipment, Kazakh National Research Technical University named after K.I. Satpayev, 22 Satpayev St, 050013, Almaty, Kazakhstan. E-mail: leonkr38@mail.ru

Yuriy Shaposhnik, Doctor of Technical Sciences, Senior Researcher of the Laboratory of Physical and Technical Geotechnology, Institute of Mining named after N.A. Chinakal of the Siberian Branch of the Russian Academy of Sciences, 54 Krasny Ave., 630091, Novosibirsk, Russian Federation. E-mail: shaposhnikyury@mail.ru

Sergey Shaposhnik, Doctor of Technical Sciences, Professor of the Department of Geomechanics and Mining, D. Serikbaev East-Kazakhstan State Technical University, 69 Protozanov St, 70004, Ust-Kamenogorsk, Kazakhstan. E-mail: shaposhniksergey@mail.ru

Anton Konurin, Candidate of Technical Sciences, Senior Researcher of the Laboratory of Physical and Technical Geotechnology, Institute of Mining named after N.A. Chinakal of the Siberian Branch of the Russian Academy of Sciences, 54 Krasny Ave., 630091, Novosibirsk, Russian Federation. E-mail: anton.konurin@gmail.com

Denis Shokarev, Mining Engineer of the LLP “Expert PRO”, 47 Protozanov St., 070004, Ust-Kamenogorsk, Kazakhstan. E-mail: denshok82@mail.ru 